\title{
Downregulation of Prominin 1/CD133 expression in colorectal cancer by NSAIDs following short-term preoperative treatment
}

\author{
CHRISTINA LÖNNROTH, MARIANNE ANDERSSON, SVANTE NORDGREN and KENT LUNDHOLM \\ Department of Surgery, Institute of Clinical Sciences, Sahlgrenska Academy, \\ Surgical Metabolic Research Laboratory at Lundberg Laboratory for Cancer Research, \\ Sahlgrenska University Hospital, University of Gothenburg, Gothenburg, Sweden
}

Received March 9, 2012; Accepted April 12, 2012

DOI: $10.3892 /$ ijo.2012.1460

\begin{abstract}
Expression of Prominin 1/CD133 is associated with poor prognosis and chemoresistance in several types of solid tumors. The aim of the present study was, therefore, to evaluate Prominin 1/CD133 expression in colorectal carcinoma after short-term preoperative treatment by non-steroidal anti-inflammatory drugs (NSAIDs). Patients aimed at curative operation for colon cancer were randomized to receive NSAIDs (indomethacin $50 \mathrm{mg}$ x2 or celecoxib $100 \mathrm{mg}$ x2) three days preoperatively. Antisecretory prophylaxis (esomeprasol $40 \mathrm{mg} \times 1$ ) was provided to all patients and served as sham intake. CD133 expression in tumor tissue was also assessed in tumors from Dukes' B patients selected for either long or short postoperative survival. No patients received perioperative chemoradiotherapy. Tumor tissue was collected at surgery for quantification of mRNAs (Prom1 and Wnt4) by qPCR. Immunohistochemistry stained for CD133, Ep-CAM, CD34 and CD45. PGE $_{2}$ content in tumor tissue was determined. Transcript of CD133 in tumor tissue was lower in patients treated with NSAIDs $(0.28 \pm 0.07$ vs. $0.51 \pm 0.08$; $\mathrm{p}<0.03)$ as well as some other stem cell-related transcripts. In treated patients $36 \%$ of all tumors stained positive for CD133 compared to $71 \%$ in sham-treated control patients $(\mathrm{p}<0.05)$. Short survivors with Dukes' B tumors displayed 78\% CD133 expression as compared to $33 \%$ of tumors in long-term survivors $(\mathrm{p}<0.002)$. Tumor tissue $\mathrm{PGE}_{2}$ content was negatively related to patient survival. Our results show that short-term preoperative NSAID treatment downregulates colon cancer tissue expression of Prominin 1/CD133, a stem cell marker indicative of survival prognosis as confirmed.
\end{abstract}

\section{Introduction}

Short-term preoperative treatment of patients with colorectal cancer with non-steroidal anti-inflammatory drugs (NSAIDs)

Correspondence to: Dr Christina Lönnroth, Department of Surgery, Sahlgrenska University Hospital, SE 41345 Gothenburg, Sweden E-mail: christina.lonnroth@surgery.gu.se

Key words: Prominin 1/CD133, colorectal cancer, indomethacin, non-steroidal anti-inflammatory drugs increased tumor tissue infiltration of activated immune cells with subsequent evidence of tumor growth inhibition and increased apoptosis (1-3). Gene expression profiles, based on whole genome oligo microarray, indicated downregulation of Prominin 1 expression which is a potential tumor stem cell marker located on chromosome 4p15.32 (4). This gene codes for a five-transmembrane glycoprotein referred to as CD133/ AC133 originally described as a cell surface antigen present on $\mathrm{CD} 34^{+}$hematopoietic stem and progenitor cells $(4,5)$. CD133 is regarded a marker of cancer stem cells related to tumor initiation and progression, although a more extended distribution of CD133/AC133 expression on cells has been reported $(6,7)$. Accordingly, there is now an increasing number of studies showing that CD133 expression may serve as an independent significant marker for prognosis and chemoresistance in colorectal cancer as well as in other solid tumor types (8-10). Thus, our unpublished microarray information implied that a pool of cancer stem cells in colorectal cancer may be sensitive to NSAID-treatment in line with other well-recognized observations on prostanoid metabolism and progression of colorectal cancer in our laboratory $(2,11-13)$. Decreased CD133 expression in colorectal tumors, subsequent to NSAID-treatment, suggests that tumor stem cells in colorectal cancer tissue may either induce differentiation with subsequent loss of CD133 expression or reflect a decline in the pool of tumor stem cells, perhaps due to increased apoptosis. The aim of the present study was to focus on Prominin 1 expression as a possible marker of tumor stem cells in relationship to short-term preoperative NSAID treatment in colon cancer from unselected patients.

\section{Materials and methods}

Patients. Unselected patients who were scheduled for primary and curative resection of colorectal cancer were randomized to receive NSAID or sham treatment during three days before surgery, between 1998 and 2004 at Sahlgrenska University Hospital, Gothenburg, Sweden, as described elsewhere (1). The patient group consisted of 16 females and 12 males with a median age of $74 \pm 9$ (SD) years (range 55-85 years). Tumors were histologically classified by certified pathologists as Dukes' A ( $n=5), B(n=10), C(n=11)$ and $D(n=1)$ corresponding to tumor stage I-IV (Table I). NSAID treatment was indomethacin (Confortid, 50 mg x2, Alpharma, $\mathrm{n}=10)$ or Celebrex (100 mg x2, 
Pfizer, $n=4)$ during three preoperative days, together with antisecretory prophylaxis (esomeprasol, $40 \mathrm{mg}$ x1, Astra Zeneca, $\mathrm{n}=14$ ), which was also provided to control patients as sham treatment. Assessment of this NSAID medication efficacy has been described elsewhere (1). None of our patients received perioperative radiochemotherapy according to standard treatment criteria at our institution and individual patient evaluations at the time of patients inclusion.

We have earlier reported that colorectal cancer patients with Dukes' B tumors and carcinoembryonic antigen (CEA) serum levels above $15-20 \mathrm{ng} / \mathrm{ml}$ at primary operations may be regarded high risk patients in agreement with reported positive correlation between CEA and elevated CD133 expression from PBMC with recurrent disease $(14,15)$. Therefore, we have also analyzed tumor expression of CD133 occurrence in selected Dukes' B patients with long or short survival. Dukes' B patients were collected from the same cohort as present study and control patients. Thus, eleven additional patients selected for care due to colorectal carcinomas classified as Dukes' B without preoperative NSAIDs were used. Eighteen such patients were divided into short (median 658 days, Mv $620 \pm 161, \mathrm{n}=9$ ) and long-term survivors (median 3,760 days, Mv 3370 $\pm 471, n=9$ ) and analyzed as a reference group in addition to analyses on the randomized study and control patients (Table I).

Tumor and colon tissue material. Tumor and normal colon tissue (down to the serosa layer) were collected at surgery, snap-frozen in liquid nitrogen and stored in $-70^{\circ} \mathrm{C}$ until analysis. For practical reasons, recent samples were kept in RNAlater (Ambion) for $24 \mathrm{~h}$ at $4^{\circ} \mathrm{C}$ and kept at $-20^{\circ} \mathrm{C}$ until analysis. Comparison of frozen and RNAlater solid tissue storage methods, as performed by Mutter et al showed a variation comparable to replicate samples run on RNA expression microarrays (16). Biopsies were kept in $4 \%$ buffered formaldehyde solution for 3 days at $4{ }^{\circ} \mathrm{C}$, washed and kept in $70 \%$ ethanol until dehydration and paraffin-embedding for immunohistochemistry. A tissue array (BioSite, Täby, Sweden) with paraffin-embedded sections of normal colon, colon adenomas and colon adenocarcinomas (five of each) was used as reference material in CD133/AC133 protein detection.

RNA extraction and cDNA synthesis. Total RNA was extracted with RNeasy Fibrous Tissue Midi Kit (Qiagen), where DNase treatment was included according to kit protocol. Quality and quantity of RNA were checked in Agilent 2100 BioAnalyzer with RNA 6000 Nano Assay Kit (Agilent Technologies). Concentration of RNA was measured in a Nano Drop ND-1000A spectrophotometer (Nano Drop Technologies Inc.). Aliquots of total RNA were used for real-time PCR, where $1 \mu \mathrm{g}$ total RNA was reverse transcribed with ClonTech 1st Strand ${ }^{\mathrm{TM}}$ cDNA Synthesis Kit (BD Biosciences) and incubated for $1 \mathrm{~h}$ at $42^{\circ} \mathrm{C}$ followed by $5 \mathrm{~min}$ at $94^{\circ} \mathrm{C}$. Each sample was then diluted to a final volume of $100 \mu \mathrm{l}$. Reactions were run in parallel where the reverse transcriptase was omitted in negative controls.

Microarray expression profiling. Microarrays were run as described earlier (1).

Real-time $q P C R$. PCR was performed in a LightCycler 1.5 with LightCycler Fast Start DNA Master ${ }^{\text {Plus }}$ (Roche). Primers for hProminin 1 (NM_006017), sense 5'-TGG ATG CAG AAC
TTG ACA ACG T-3' (17) and antisense 5'-TGC TCG TGT AAG GTT CAC AGA T-3' (CyberGene AB, Novum Research Park, Huddinge, Sweden) were added to capillaries in a final concentration of $0.5 \mu \mathrm{M}$. Two microliters cDNA was used for each amplification with reagents from LightCycler Fast Start DNA MasterPlus SYBR-Green 1 Kit (code 03515885001, Roche), with conditions: $95^{\circ} \mathrm{C}$ for $10 \mathrm{~min}$ initially, then 40 cycles with $95^{\circ} \mathrm{C}$ for $10 \mathrm{sec}, 58^{\circ} \mathrm{C}$ for $7 \mathrm{sec}$ and $72^{\circ} \mathrm{C}$ for $22 \mathrm{sec}$. QuantiTect Primer Assay HS_WNT4_11_S6 (cat no. QT00041391) and QuantiTect SYBR-Green PCR Kit (cat no. 204143, Qiagen) were used for amplification of Wnt 4 with following conditions: $95^{\circ} \mathrm{C}$ for 15 min initially, then 45 cycles with $94^{\circ} \mathrm{C}$ for $15 \mathrm{sec}, 55^{\circ} \mathrm{C}$ for $20 \mathrm{sec}$ and $72^{\circ} \mathrm{C}$ for $20 \mathrm{sec}$. Samples were performed in duplicates and related to expression of glyceraldehyde-3-phosphate dehydrogenase (GAPDH, Control Amplimer Set, 639003, BD Biosciences) as least variable of eleven tested housekeeping genes (13). Quantitative results were derived by use of the relative standard curve method where standard specimen was cDNA from an untreated human colon tumor (Dukes' C), resected at Sahlgrenska University Hospital. The expected size of $552 \mathrm{bp}$ (Prom1) and $550 \mathrm{bp}$ (GAPDH) and $129 \mathrm{bp}$ (Wnt4) was confirmed in Agilent 2100 BioAnalyzer with DNA 100 reagents. Reactions were confirmed by positive and negative controls (one dilution of standard curve cDNA respective water substituted for cDNA).

Immunohistochemistry. Formalin-fixed and paraffin-embedded tissue sections $(4 \mu \mathrm{m})$ were deparaffinized and rehydrated according to standard procedures and rinsed twice in $5 \mathrm{mM}$ Tris Buffered Saline (TBS), pH 7.8. Sections were microwaveradiated in $0.01 \mathrm{M}$ citrate buffer, pH 6.1 (Dako, S1700). Sections were mounted with Shandon Coverplates after TBS-rinse. Non-specific protein binding was initially blocked with TBS containing 5\% fat-free dry milk followed by the procedure in EnVision Dual Link System-HRP (K4065, Dako Cytomation). Monoclonal mouse anti-human CD133/1 (AC133, 130-090-422, Miltenyi Biotech, $15 \mu \mathrm{g} / \mathrm{ml}$ ) was used for detection of CD133. Mouse IgG1 (Dako 0931, $15 \mu \mathrm{g} / \mathrm{ml}$ ) was used as negative control. Diaminobenzidine (DAB), included in the EnVision kit was used as chromogen. Counterstaining was performed in Mayer's hematoxylin and mounting was done in Pertex following dehydration (Histolab Products, Gothenburg, Sweden). The EnVision Doublestain Kit (K1395, Dako Cytomation) was used for dual staining of CD133/Ep-CAM, CD133/CD34 and CD133/CD45 to evaluate stem/progenitor cell origin; epithelial, lymphohematopoietic or lymphoid. Two clones for detection of EP-CAM were used simultaneously: monoclonal mouse anti-human epithelial antigen, MOC-31 (M3525, Dako Cytomation, conc. $1.0 \mu \mathrm{g} / \mathrm{ml}$ ) and monoclonal mouse Ber-EP4 (M0804, DakoCytomation, conc. $1.25 \mu \mathrm{g} / \mathrm{ml}$ ). Mouse monoclonal anti-human CD34 (sc-19621, Santa Cruz, conc. $4 \mu \mathrm{g} / \mathrm{ml}$ ) was used for lymphohematopoietic cell detection and mouse monoclonal anti-human CD45, Leucocyte Common Antigen (M0701, DakoCytomation, conc. $4 \mu \mathrm{g} / \mathrm{ml}$ ) for lymphoid cell detection. Incubation conditions for Ber-EP 4, MOC-31, CD34 and CD45 were $60 \mathrm{~min}$ at $\mathrm{RT}$ and for CD133 $2 \mathrm{~h}$ at $\mathrm{RT}+\mathrm{ON}$ at $4^{\circ} \mathrm{C}$. Otherwise IHC was run according to kit protocols. CD133 stained red (Fast Red) and Ep-CAM, CD34 and CD45 stained brown $\left(\mathrm{Dab}^{+}\right)$. Doublestained sections were mounted in aqueous medium Faramount (Dako Cytomation) following counterstaining. Observations of protein appearance and distribution of antibody 
Table I. Patient characteristics before operation in patients randomized to NSAID or sham treatment and in selected reference patients with Dukes' B tumors with confirmed short- and long-term survival.

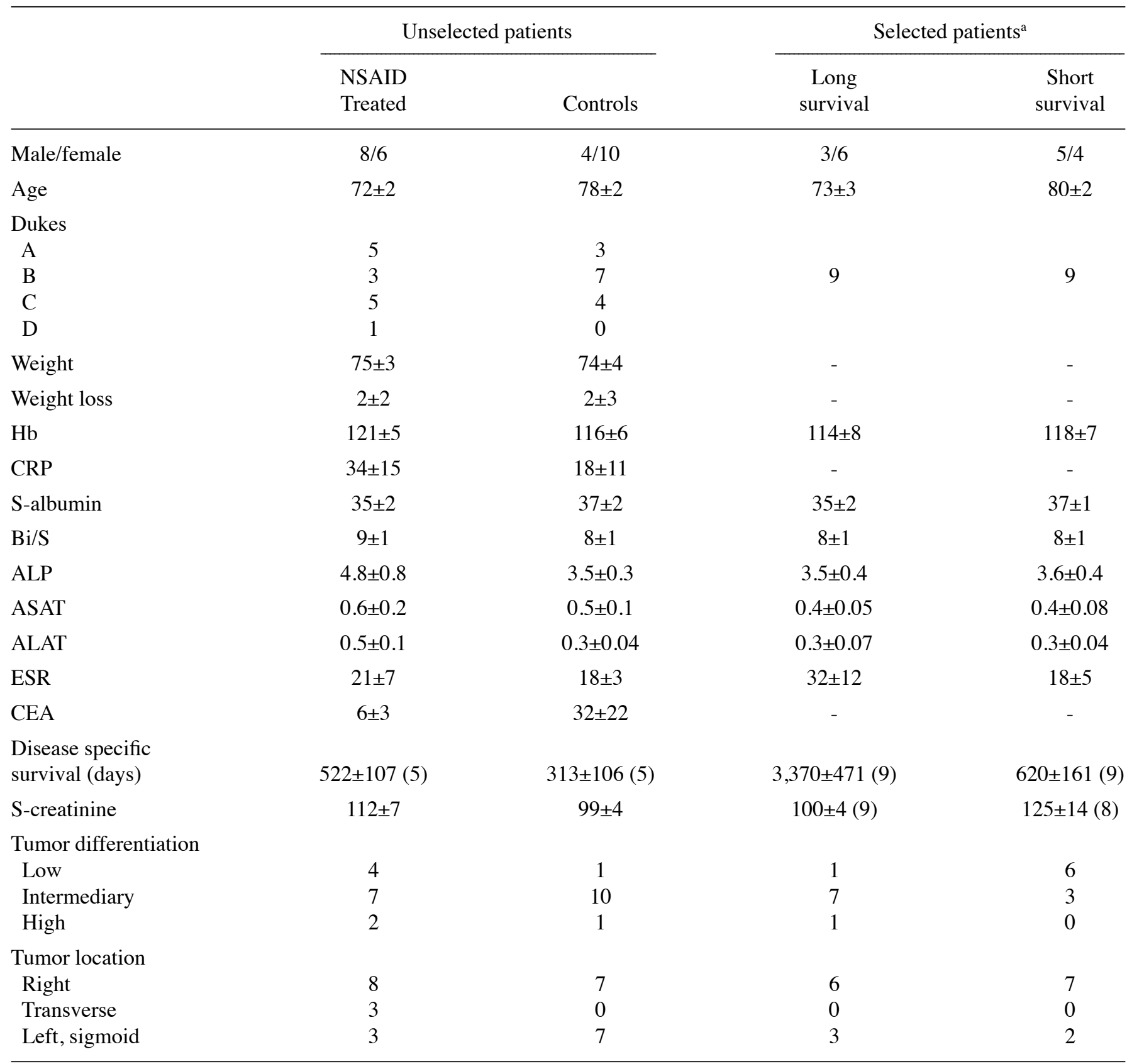

aDukes' B tumors with short- and long-term mean survival; mean \pm SEM.

stained cells were performed in Nikon eclipse E400 microscope and Digital HyperHAD Color Video Camera (Sony) using the Easy Image analysis software (Tekno Optik AB, Sweden).

$P G E_{2}$ analysis in tumor tissue. A radioimmunoassay (Amersham, RPA 530) was used following pretreatment of tumor tissue as described earlier (11).

Statistics. Results are presented as mean \pm SEM and median values when appropriate. Non-parametric statistics were used in group comparisons (Mann-Whitney U-test and $\chi^{2}$ test). This study was approved by the Regional Ethics Review Board, University of Gothenburg. Clinical Trials (NCT00473980).

\section{Results}

Real-time $q P C R$. Transcript content of CD133/GAPDH in tumor tissue RNA from individual patients was significantly lower in patients treated with NSAID compared to control patients $(0.28 \pm 0.07$ vs. $0.51 \pm 0.08 ; \mathrm{p}<0.03)$. Similar results were obtained in array assays suggesting that several stem cell-related proteins were altered by NSAIDs treatment (Table II). Parts of these alterations included signaling across Wnt4 pathways, which was also confirmed by qPCR, where NSAID-treated patients had tumors with a mean rank of 10.7 $(n=13)$ compared to $17.1(n=14)$ in sham-treated control patients $(\mathrm{p}<0.04)$ (Table II). 
Table II. Transcript alterations of stem-cell related proteins in colorectal cancer from patients randomized to preoperative NSAID treatment versus sham-treated controls as described in Materials and methods.

\begin{tabular}{|c|c|c|c|c|}
\hline $\begin{array}{l}\text { Systematic } \\
\text { name }\end{array}$ & $\begin{array}{l}\text { Gene } \\
\text { name }\end{array}$ & Descriptive name & $\begin{array}{l}\text { Array } \\
\text { ratio }\end{array}$ & $\begin{array}{c}\text { Number of } \\
\text { arrays with } \\
\mathrm{p}<0.05\end{array}$ \\
\hline NM_006017 & Prom1 & Homo sapiens prominin 1 & $0.57 \pm 0.13^{\mathrm{a}}$ & $2 / 3$ \\
\hline NM_030761 & Wnt4 & $\begin{array}{l}\text { Homo sapiens wingless-type MMTV integration site } \\
\text { family, member } 4 \text { (WNT4), mRNA }\end{array}$ & $0.34 \pm 0.07^{\mathrm{a}}$ & $3 / 3$ \\
\hline NM_006129 & BMP1 & $\begin{array}{l}\text { Homo sapiens bone morphogenetic protein } 1 \\
\text { (BMP1), transcript variant BMP1-3, mRNA }\end{array}$ & $0.25 \pm 0.04$ & $3 / 3$ \\
\hline NM_001718 & BMP6 & $\begin{array}{l}\text { Homo sapiens bone morphogenetic protein } 6 \\
\text { (BMP6), mRNA }\end{array}$ & $0.58 \pm 0.28$ & $2 / 3$ \\
\hline NM_001719 & BMP7 & $\begin{array}{l}\text { Homo sapiens bone morphogenetic protein } 7 \\
\text { (osteogenetic protein 1) (BMP7), mRNA }\end{array}$ & $0.50 \pm 0.03$ & $3 / 3$ \\
\hline NM_000215 & JAK3 & $\begin{array}{l}\text { Homo sapiens Janus kinase } 3 \text { (a protein tyrosine } \\
\text { kinase, leukocyte) (JAK3), mRNA }\end{array}$ & $0.57 \pm 0.15$ & $2 / 3$ \\
\hline I_958344 & LIFR & $\begin{array}{l}\text { Leukemia inhibitory factor receptor, forms cytokine } \\
\text { receptors in association with CNTFR and the IL6 } \\
\text { receptor signaling subunit (IL6ST), signals through } \\
\text { the JAK-STAT cascade; translocation of the } \\
\text { corresponding gene promoter causes salivary gland } \\
\text { adenomas }\end{array}$ & $0.45 \pm 0.04$ & $3 / 3$ \\
\hline
\end{tabular}

Mean \pm SEM; ${ }^{a}$ ratios were 0.55 (Prom1) and 0.63 (Wtn4) respectively when confirmed by qPCR as described in Materials and methods; Wnt4 expression confirmed by qPCR showed that NSAID-treated tumor tissue had a mean rank of $10.7(\mathrm{n}=13)$ compared to 17.1 ( $\mathrm{n}=14)$ in tumors from sham-treated control patients $(\mathrm{p}<0.04)$.

Table III. Tumor tissue PGE2 content at surgical resection for cure in relationship to tumor tissue content of protein and RNA transcripts of CD133 assessed by immunohistochemistry and qPCR.

\begin{tabular}{|c|c|c|c|}
\hline Patient group & $\begin{array}{l}\text { Tumor PGE2 } \\
\mathrm{pg} / \mathrm{g} \text { tissue }\end{array}$ & $\begin{array}{l}\text { IHC CD133 } \\
\text { positivity }\end{array}$ & $\begin{array}{l}\text { qPCR ratio } \\
\text { CD133/GAPDH }\end{array}$ \\
\hline $\begin{array}{l}\text { Unselected non-treated } \\
\text { controls }\end{array}$ & $\begin{array}{l}24,120(n=11) \\
34,424 \pm 11,181\end{array}$ & $10 / 14$ & $\begin{array}{l}0.42(n=14) \\
0.51 \pm 0.08\end{array}$ \\
\hline $\begin{array}{l}\text { Unselected NSAID- } \\
\text { treated }\end{array}$ & $\begin{array}{l}2,200(\mathrm{n}=11)^{\mathrm{a}} \\
4,065 \pm 1840\end{array}$ & $5 / 14^{\mathrm{e}}$ & $\begin{array}{l}0.27(n=14)^{b} \\
0.28 \pm 0.07\end{array}$ \\
\hline $\begin{array}{l}\text { Non-treated CD } 133^{-} \\
\text {(IHC) controls }\end{array}$ & $\begin{array}{l}15,663(\mathrm{n}=10)^{\mathrm{c}} \\
46,549 \pm 18,681\end{array}$ & $0 / 10$ & $\begin{array}{l}0.39(n=4) \\
0.38 \pm 0.04\end{array}$ \\
\hline $\begin{array}{l}\text { Non-treated CD } 133^{+} \\
\text {(IHC) controls }\end{array}$ & $\begin{array}{l}8,205(\mathrm{n}=12) \\
15,466 \pm 5,794\end{array}$ & $15 / 15$ & $\begin{array}{l}0.45(n=10) \\
0.56 \pm 0.11\end{array}$ \\
\hline $\begin{array}{l}\text { NSAID-treated } \\
\text { CD133- }^{-} \text {(IHC) }\end{array}$ & $\begin{array}{l}3,750(n=6) \\
6,572 \pm 3,081\end{array}$ & $0 / 9$ & $\begin{array}{l}0.07(n=9) \\
0.28 \pm 0.12\end{array}$ \\
\hline $\begin{array}{l}\text { NSAID-treated } \\
\text { CD } 133^{+}(\mathrm{IHC})\end{array}$ & $\begin{array}{l}384(\mathrm{n}=5) \\
1,056 \pm 489\end{array}$ & $5 / 5$ & $\begin{array}{l}0.28(n=5) \\
0.28 \pm 0.04\end{array}$ \\
\hline $\begin{array}{l}\text { Selected Dukes' B } \\
\text { long survival }\end{array}$ & $\begin{array}{l}15,163(n=8) \\
41,592 \pm 21,369\end{array}$ & $3 / 9^{d}$ & $\begin{array}{l}0.32(n=4) \\
0.34 \pm 0.04\end{array}$ \\
\hline $\begin{array}{l}\text { Selected Dukes' B } \\
\text { short survival }\end{array}$ & $\begin{array}{l}10,625(\mathrm{n}=8) \\
12,838 \pm 4,008\end{array}$ & $7 / 9$ & $\begin{array}{l}0.40(n=3) \\
0.44 \pm 0.18\end{array}$ \\
\hline
\end{tabular}

Median values and mean $\pm \mathrm{SEM} ;{ }^{\mathrm{a}} \mathrm{p}<0.01$ Mann-Whitney U-test; ${ }^{\mathrm{b}} \mathrm{p}<0.05$ Mann-Whitney U-test; ${ }^{\mathrm{c}} \mathrm{p}<0.1$ Mann-Whitney U-test; ${ }^{\mathrm{d}} \mathrm{p}<0.002 \chi^{2}$ test; ${ }^{\mathrm{e}} \mathrm{p}<0.05 \chi^{2}$ test. 
A

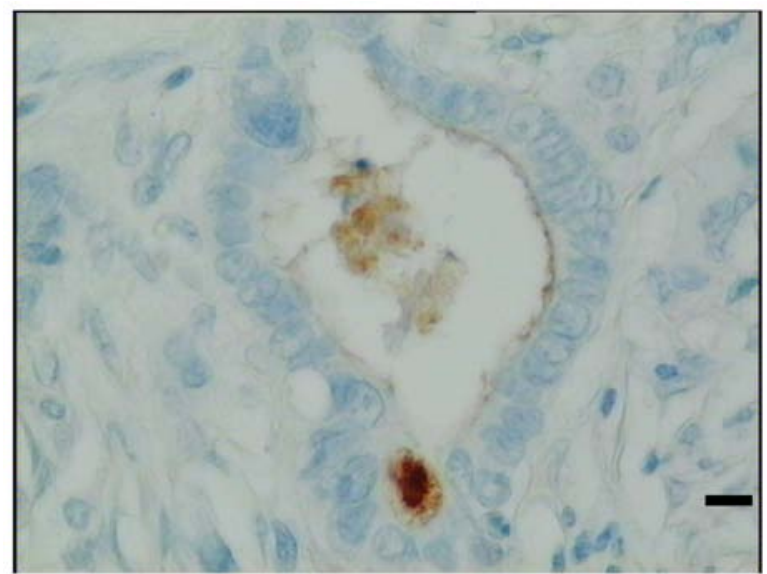

B

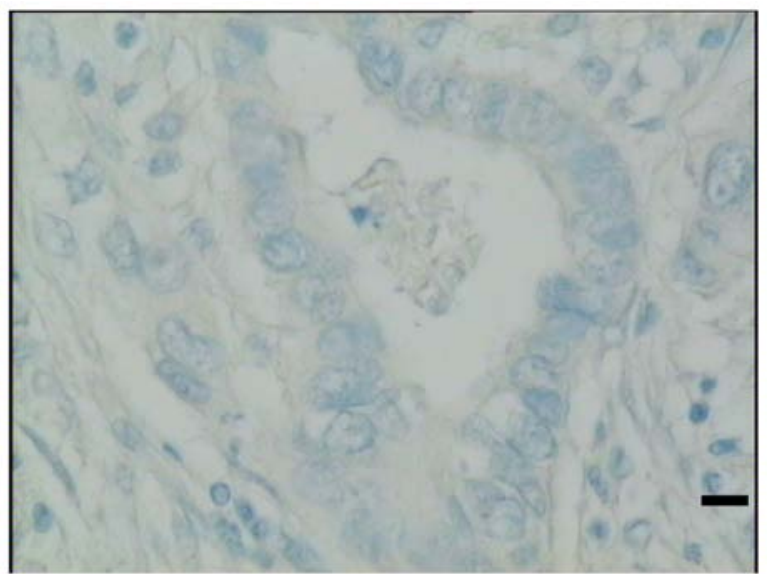

Figure 1. Immunohistochemistry of colon tumor tissue sections from control patient, showing CD133 glycosylated epitope staining in tumor gland formation. (A) Protein (brown) is seen in the apical plasma membrane, as well as in luminally shed cells. (B) Negative control. Background nuclei stain blue. Original magnification, $\mathrm{x} 400$; bars, $10 \mu \mathrm{m}$.

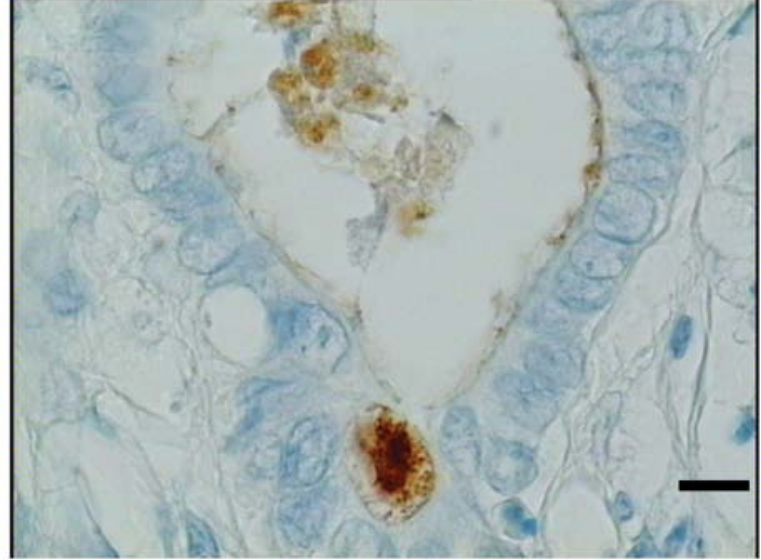

Figure 2. Shows Fig. 1A in a larger magnification, x600. Bar, $10 \mu \mathrm{m}$.

Immunohistochemistry. CD133 staining appeared in apical plasma membrane of epithelial tumor gland formations and mostly in lumina where the shed cells seemed to spread CD133-containing particles. Non-cellular, CD133-positive material was observed in the same location (Figs. 1-3), which agreed with results reported by others $(8,9)$. Different locations were seen for CD133 and CD45 expressing cells (Fig. 3) and coexpressions of CD133, CD34 and CD45 were only observed occasionally in tumor tissue specimens. Consecutive sections illustrate location of the four antibodies, here shown in single staining for easier visualization (Fig. 4). Normal colon sections from individual cancer patients did not stain positive for AC133 (not shown). On sections of commercially available tissue array, 60\% (3/5) of colon carcinomas stained positive for CD133, while colon adenomas and normal colon sections were negative (Fig. 5).

Five NSAID treated patients (36\%) had tumors that stained positive for CD133 compared to tumors in 10 control patients $(71 \%)(\mathrm{p}<0.05)$ (Table III). The mean rank of staining scores (distribution $\mathrm{x}$ staining intensity) in NSAID treated tumors was numerically lower compared to scores in control patients, but did not reach statistical significance $(\mathrm{p}<0.19)$.
In patients with selected high risk Dukes' B tumors, CD133 was detected in 78\% (7/9) of tumors from patients with short survival (median 658 days), and in 33\% (3/9) of tumors from patients with 5-fold longer survival (median 3,760 days) $(\mathrm{p}<0.002)$ (Table III).

$P G E_{2}$ analysis. Tumor tissue content of $\mathrm{PGE}_{2}$ was $4,065 \pm 1,840 \mathrm{pg} / \mathrm{g}$ tissue $(\mathrm{n}=11)$ and $34,427 \pm 11,181 \mathrm{pg} / \mathrm{g}$ tissue $(\mathrm{n}=11)$ in NSAID-treated and control patients, respectively $(\mathrm{p}<0.01)$. In selected Dukes' B patients, tumor tissue content of $\mathrm{PGE}_{2}$ was $41,592 \pm 21,369 \mathrm{pg} / \mathrm{g}(\mathrm{n}=8)$ and $12,838 \pm 4,008 \mathrm{pg} / \mathrm{g}(\mathrm{n}=8)$ in long-term and short-term survivors respectively (Table III). Non-treated CD133' colon cancer (controls) had 46,549 $\pm 18,681 \mathrm{pg} / \mathrm{g} \mathrm{PGE}_{2}$ in tumor tissue $(\mathrm{n}=10)$ compared to $\mathrm{CD}_{133^{+}}$tumors from controls, which had $15,466 \pm 5,794 \mathrm{pg} / \mathrm{g}(\mathrm{n}=12)(\mathrm{p}<0.1)$ (Table III).

\section{Discussion}

Our previous studies have demonstrated that tumor growth and patient survival relate to local tumor and systemic effects communicated by cytokines, classical hormones and prostanoids in part communicated by EP subtype receptor expression in colorectal cancer (2). Accordingly our previous observations showed that even short-term preoperative NSAID treatment seemed to reprogram inflammatory cells to re-express antitumor defense mechanisms (1). In such tumor specimens it has also been observed that tumor cellular events are coordinated by altered direct and indirect prostanoid activities in tumor and host tissues. However, in the present study, CD133 expression did not seem to be directly related to net prostaglandin $\left(\mathrm{PGE}_{2}\right)$ content in tumor tissue, which may accord with reports by others $(9,18)$. Stem cell homeostasis is by several investigators regarded a significant avenue for intensive exploration, where our present results demonstrate that CD133 was significantly decreased at both mRNA and protein levels, including other stem cell associated mRNAs following short-term preoperative NSAID treatment of patients with colon carcinoma (Table II). Our findings are in agreement with studies by Deng et al where Celecoxib downregulated CD133 expression at mRNA and 


\section{A}

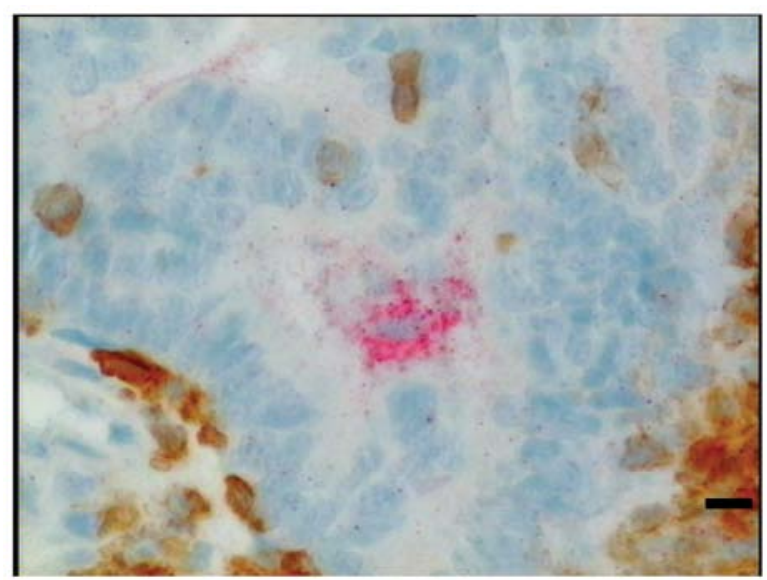

B

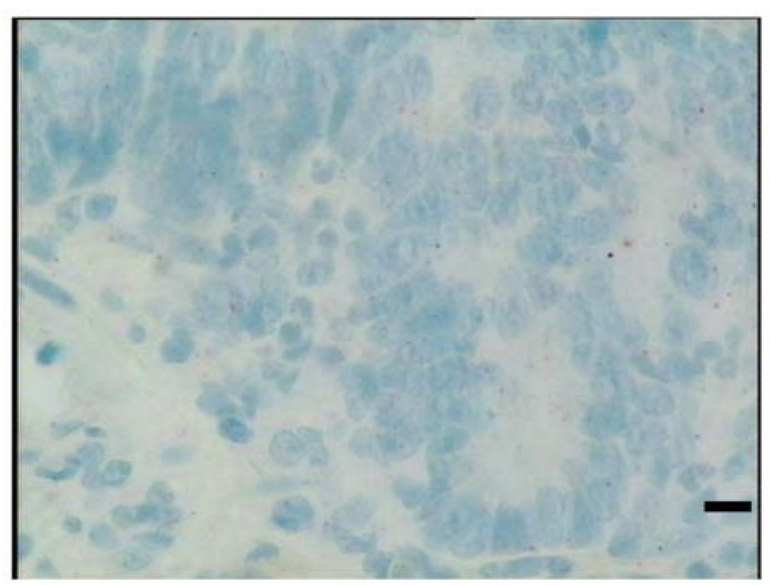

Figure 3. Immunohistochemistry of colon tumor tissue sections from NSAID-treated patient. (A) Double staining shows CD133 epitope in red, while brown staining indicates CD45 in lymphoid cells. (B) Negative control. Background nuclei stain blue. Original magnification, x400; bars, $10 \mu \mathrm{m}$.

A
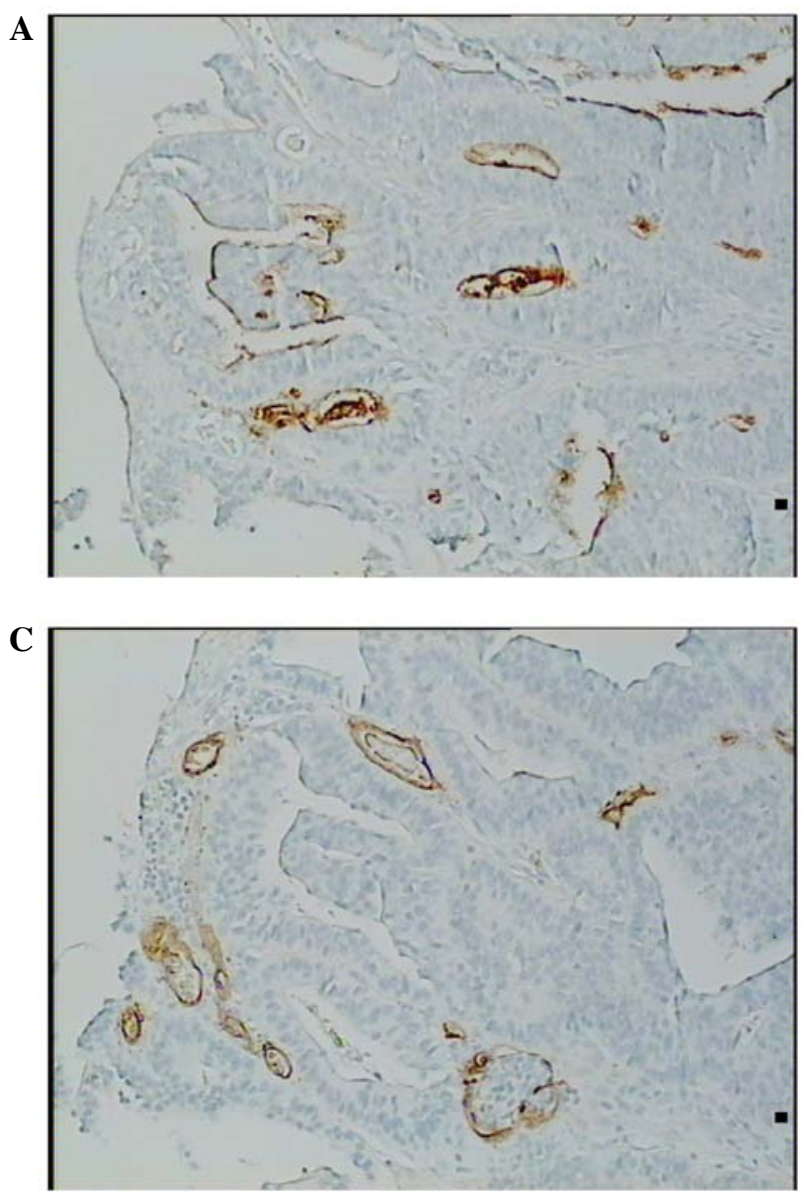

B

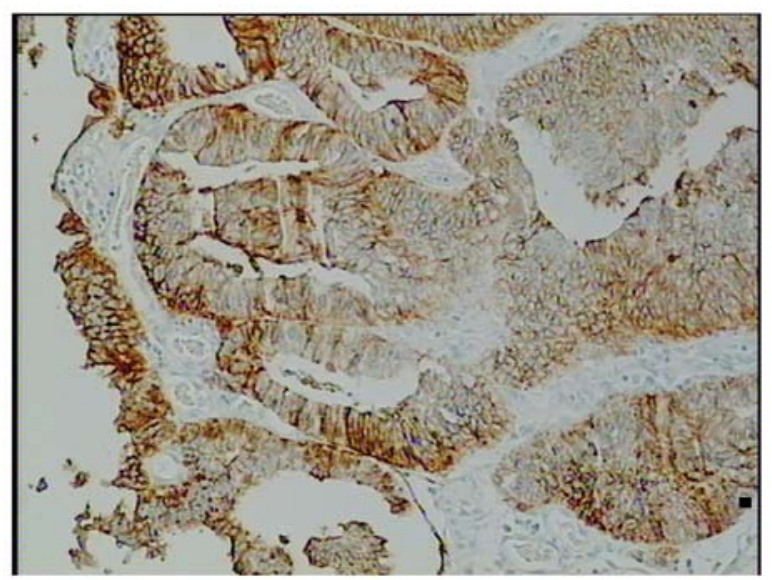

D

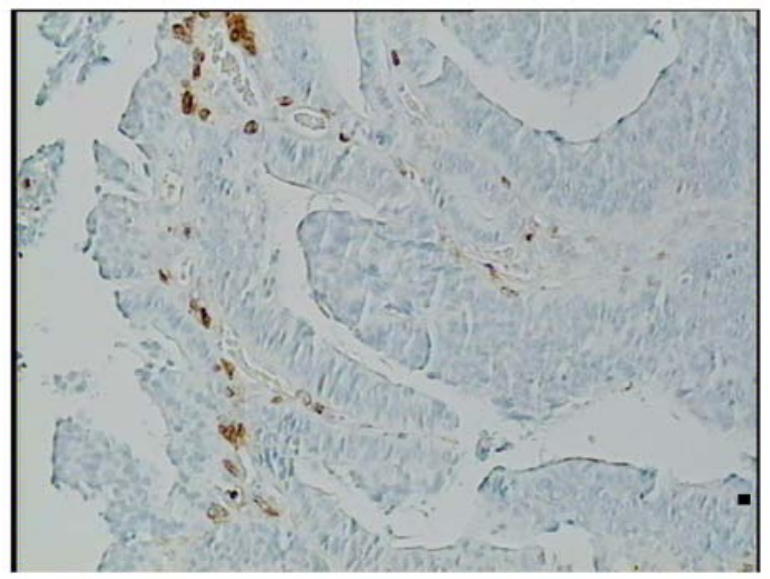

Figure 4. Immunohistochemistry of colon tumor tissue sections from control patient, showing (A) staining of glycosylated epitope of CD133 protein, (B) epithelial antigen EpCAM, (C) endothelial marker CD34 and (D) lympoid marker CD45. Proteins stain brown, background nuclei stain blue. CD133 expressing cells are located within the tumor epithelial area. Original magnification, $\mathrm{x} 100$; bars, $10 \mu \mathrm{m}$.

protein levels in colon cancer cell lines and in primary colon cancer spheres (19). Addition of $\mathrm{PGE}_{2}$ in their experiments did not restore the effect of NSAID on CD133 expression.

CD133 expression also appeared to be a prognostic marker as supported by our present observations in patients with Dukes' B tumors selected according to short and extended survival as related to different $\mathrm{CD} 133$ protein expression $(\mathrm{p}<0.002)$.
Our present observations may agree with our previous findings that NSAID treatment showed a trend to prolong survival in cancer patients with progressive systemic disease (12), at least in part related to confirmed effects to attenuate prostanoid activity in both tumor and host tissues (11). However, the relationship between $\mathrm{PGE}_{2}$ content and CD133 expression in tumor tissue in present patients appeared less clear, but may include undefined 
A

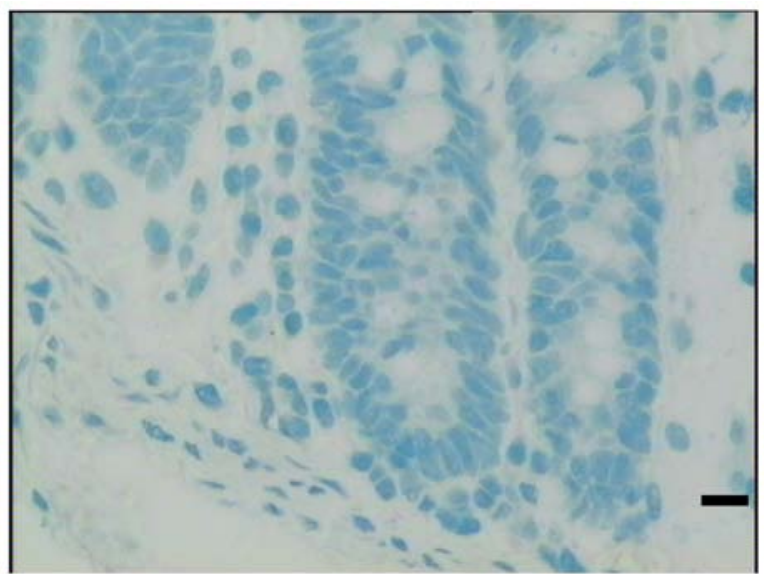

B

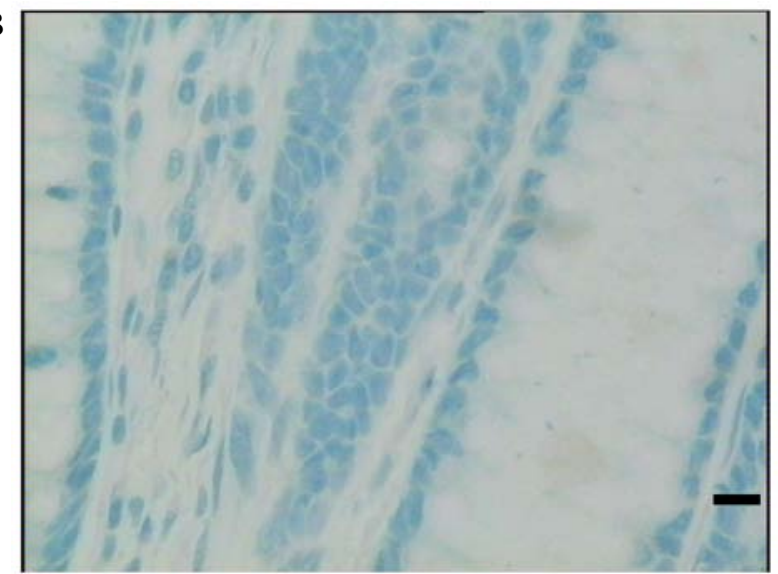

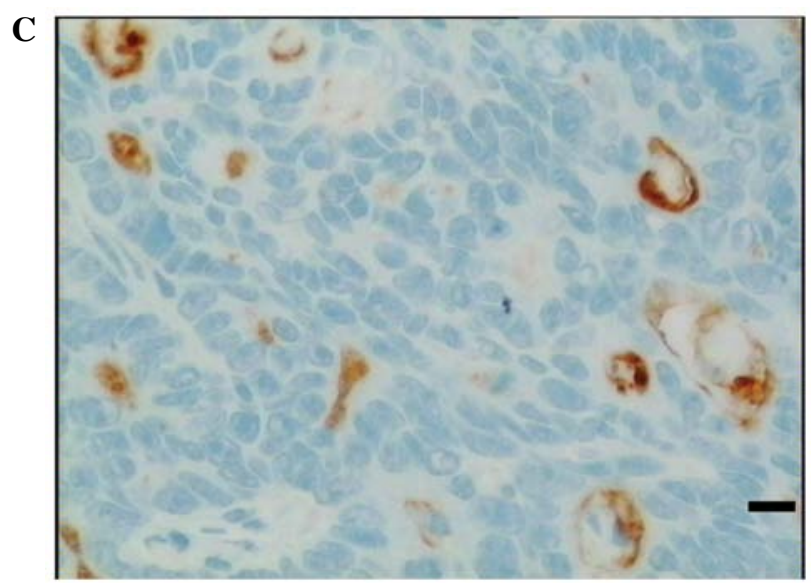

Figure 5. Immunohistochemistry of a commercially human tissue array with (A) normal colon, (B) colon adenoma and (C) colon adenocarcinoma. Glycosylated epitope of CD133 protein stains brown and is seen only in $(\mathrm{C})$. Background nuclei stain blue. Original magnification, $\mathrm{x} 400$; bars, $10 \mu \mathrm{m}$.

off-target effects by NSAIDs, as well as net cell effects among different endothelial and stroma cells in part communicated by Wnt 4 signaling (Table II) (20).

The Prominin 1/CD133 gene is composed of at least 27 exons with five alternative promoters and several splice variants with the possibility of various glycosylation of different splice variants (21-23). CD133-1/AC133 is usually expressed in plasma membrane protrusions of different cell types, mostly associated with cholesterol in lipid rafts, perhaps participating in cell migration and polarization (24-26). The biological function of CD133 is yet unclear but is reported to relate to glucose metabolism and cytoskeleton alterations in addition to roles in embryogenesis and wound repairing processes that involve recruitment of circulating endothelial precursor cells derived from $\mathrm{CD} 34^{+} / \mathrm{CD} 133^{+}$hematopoietic precursors $(27,28)$.

Tumor effects with inhibition of immune cells may in part depend on exosomal transfer of structural biological information. The appearance of AC133-containing buddings with released biological material, as observed in our present material, may well represent a system for horizontal transfer of information among cells. Accordingly, previous studies have reported that shedded membrane particles carry messages without the need of direct cell-to-cell contact. Such communications may occur in both normal and neoplastic tissues representing transportation of proteins, mRNA, DNA, miRNA, virus- and prion particles and perhaps also organelles as mitochondria (29-42). Tumor- derived secreted membrane particles have thus been implied in deregulation of immunoreactions promoting tumor invasion, metastasis, inflammation and angiogenesis $(43,44)$, suggestions that agree with our previous observations on immune activation of tumor infiltrating cells following NSAID treatment. CD133 signaling based on extracellular membrane particles shedded from neural progenitors and epithelial cells have been named small $(50-80 \mathrm{~nm})$ and large $(0.5-1 \mu \mathrm{m})$ prominosomes appearing during brain embryogenesis, in body fluids from adult healthy humans and among Caco-2 cells upon differentiation $(45,46)$. Seen together, our previous and present information provides a speculative possibility that NSAID interactions may evoke alterations in prominosome metabolism during cell to cell communication in cancer growth and perhaps also in tissue regeneration pending that growing tumors and healing wounds may represent two sides of a coin $(3,12,47-51)$.

In conclusion, our previous report on immune activation in tumor tissue by short-term preoperative treatment with NSAIDs to colon cancer patients is now extended to involve the possibility of altered tumor stem cell dynamics. Previous experiments in our laboratory have indicated that prostanoid activity as well as telomerase activity control decreased tumor cell proliferation and increased apoptosis observed in colon cancer specimens (47). Also, the appearance of extracellular membrane particles in tumor tissue as demonstrated in present images is expected to support transfer of biological information among cellular 
phenotypes (Figs. 2 and 3). Our present information in relation to the effect by NSAIDs on colon cancer stem cells may relate to both target and off-target mechanisms including possible interplay between tumor, immune and stroma cells as supported by previous investigations in our laboratory (11). CD133 phenomena may include strategies for new biomarkers, prognostic factors as well as treatment targets with NSAIDs alone or in adjacent to conventional regimens.

\section{Acknowledgements}

This study was supported in part by grants from the Swedish Cancer Society (2014), the Swedish Research Council (08712), Assar Gabrielsson Foundation (AB Volvo), Jubileumskliniken Foundation, Inga-Britt \& Arne Lundberg Research Foundation, Swedish and Gothenburg Medical Societies and the Medical Faculty, University of Gothenburg, Wilhelm and Martina Lundgren Foundation.

\section{References}

1. Lönnroth C, Andersson M, Arvidsson A, Nordgren S, Brevinge H, Lagerstedt $\mathrm{K}$ and Lundholm K: Preoperative treatment with a non-steroidal antiinflammaatory drug (NSAID) increases tumor tissue infiltration of seemingly activated immune cells in colorectal cancer. Cancer Immun 8: 5, 2008.

2. Gustafsson A, Andersson M, Lagerstedt K, Lönnroth C, Nordgren S and Lundholm K: Receptor and enzyme expression for prostanoid metabolism in colorectal cancer as related to tumor tissue $\mathrm{PGE}_{2}$. Int J Oncol 36: 469-478, 2010.

3. Auman JT, Church R, Lee SY, Watson MA, Fleshman JW and McLeod HL: Celecoxib pre-treatment in human colorectal adenocarcinoma patients is associated with gene expression alterations suggestive of diminished cellular proliferation. Eur J Cancer 44: 1754-1760, 2008.

4. Miraglia S, Godfrey W, Yin AH, Atkins K, Warnke R, Holden JT, Bray RA, Waller EK and Buck DW: A novel five-transmembrane hematopoietic stem cell antigen: isolation, characterization, and molecular cloning. Blood 90: 5013-5021, 1997.

5. Yin AH, Miraglia S, Zanjani ED, Almeida-Porada G, Ogawa M, Leary AG, Olweus J, Kearney J and Buck DW: AC133, a novel marker for human hematopoietic stem and progenitor cells. Blood 90: 5002-5012, 1997.

6. Ricci-Vitiani L, Lombardi DG, Pilozzi E, Biffoni M, Todaro M, Peschle $C$ and De Maria R: Identification and expansion of human colon-cancer-initiating cells. Nature 445: 111-115, 2007.

7. Shmelkov SV, Butler JM, Hooper AT, Hormigo A, Kushner J, Milde T, St Clair R, Baljevic M, White I, Jin DK, Chadburn A, Murphy AJ, Valenzuela DM, Gale NW, Thurston G, Yancopoulos GD, D'Angelica M, Kemeny N, Lyden D and Rafii S: CD133 expression is not restricted to stem cells, and both $\mathrm{CD} 133^{+}$and CD133- metastatic colon cancer cells initiate tumors. J Clin Invest 118: 2111-2120, 2008.

8. Horst D, Kriegl L, Engel J, Kirchner T and Jung A: CD133 expression is an independent prognostic marker for low survival in colorectal cancer. Br J Cancer 99: 1285-1289, 2008.

9. Ong CW, Kim LG, Kong HH, Low LY, Iacopetta B, Soong R and Salto-Tellez M: CD133 expression predicts for non-response to chemotherapy in colorectal cancer. Mod Pathol 23: 450-457, 2010.

10. Nakamura M, Kyo S, Zhang B, Zhang X, Mizumoto $Y$, Takakura M, Maida Y, Mori N, Hashimoto M, Ohno S and Inoue M: Prognostic impact of CD133 expression as a tumorinitiating cell marker in endometrial cancer. Hum Pathol 41: 1516-1529, 2010.

11. Cahlin C, Lönnroth C, Arvidsson A, Nordgren S and Lundholm K: Growth associated proteins in tumor cells and stroma related to disease progression of colon cancer accounting for tumor tissue $\mathrm{PGE}_{2}$ content. Int $\mathrm{J}$ Oncol 32: 909-918, 2008.
12. Lundholm K, Gelin J, Hyltander A, Lonnroth C, Sandstrom R, Svaninger G, Korner U, Gulich M, Karrefors I, Norli B, Hafström L, Kewenter J, Olbe L and Lundell L: Anti-inflammatory treatment may prolong survival in undernourished patients with metastatic solid tumors. Cancer Res 54: 5602-5606, 1994.

13. Gustafsson A, Hansson E, Kressner U, Nordgren S, Andersson M, Wang W, Lonnroth C and Lundholm K: EP1-4 subtype, COX and PPARgamma receptor expression in colorectal cancer in prediction of disease-specific mortality. Int J Cancer 121: 232-240, 2007.

14. Forslund A, Engaras B, Lonnroth C and Lundholm K: Prediction of postoperative survival by preoperative serum concentrations of anti-p53 compared to CEA, CA 50, CA 242 and conventional blood tests in patients with colorectal carcinoma. Int J Oncol 20: 1013-1018, 2002

15. Lin EH, Hassan M, Li Y, Zhao H, Nooka A, Sorenson E, Xie K, Champlin R, Wu X and Li D: Elevated circulating endothelial progenitor marker CD133 messenger RNA levels predict colon cancer recurrence. Cancer 110: 534-542, 2007.

16. Mutter GL, Zahrieh D, Liu C, Neuberg D, Finkelstein D, Baker HE and Warrington JA: Comparison of frozen and RNALater solid tissue storage methods for use in RNA expression microarrays. BMC Genomics 5: 88, 2004.

17. Rabascio C, Muratori E, Mancuso P, Calleri A, Raia V, Foutz T, Cinieri S, Veronesi G, Pruneri G, Lampertico P, Iavarone M, Martinelli G, Goldhirsch A and Bertolini F: Assessing tumor angiogenesis: increased circulating VE-cadherin RNA in patients with cancer indicates viability of circulating endothelial cells. Cancer Res 64: 4373-4377, 2004.

18. Schwartzbaum JA, Huang K, Lawler S, Ding B, Yu J and Chiocca EA: Allergy and inflammatory transcriptome is predominantly negatively correlated with CD133 expression in glioblastoma. Neuro Oncol 12: 320-327, 2010.

19. Deng Y, Wang L, Taian Q, Miller C, Lin T, Chien AJ, Ulrich CM, Grady WM, Blau CA and Lin EH: Regulation of expression of CD133, a colon cancer stem cell marker and other stemness genes/pathways, by celecoxib: Clues from clinical observations. J Clin Oncol 27 (suppl) abst 15065, 2009.

20. Mizrak D, Brittan M and Alison MR: CD133: molecule of the moment. J Pathol 214: 3-9, 2008.

21. Corbeil D, Roper K, Hellwig A, Tavian M, Miraglia S, Watt SM, Simmons PJ, Peault B, Buck DW and Huttner WB: The human AC133 hematopoietic stem cell antigen is also expressed in epithelial cells and targeted to plasma membrane protrusions. J Biol Chem 275: 5512-5520, 2000.

22. Jaszai J, Fargeas CA, Florek M, Huttner WB and Corbeil D: Focus on molecules: prominin-1 (CD133). Exp Eye Res 85: 585-586, 2007.

23. Fargeas CA, Corbeil D and Huttner WB: AC133 antigen, CD133, prominin-1, prominin-2, etc.: prominin family gene products in need of a rational nomenclature. Stem Cells 21: 506-508, 2003.

24. Roper K, Corbeil D and Huttner WB: Retention of prominin in microvilli reveals distinct cholesterol-based lipid microdomains in the apical plasma membrane. Nat Cell Biol 2: 582-592, 2000.

25. Giebel B, Corbeil D, Beckmann J, Hohn J, Freund D, Giesen K, Fischer J, Kogler G and Wernet P: Segregation of lipid raft markers including CD133 in polarized human hematopoietic stem and progenitor cells. Blood 104: 2332-2338, 2004.

26. Weigmann A, Corbeil D, Hellwig A and Huttner WB: Prominin, a novel microvilli-specific polytopic membrane protein of the apical surface of epithelial cells, is targeted to plasmalemmal protrusions of non-epithelial cells. Proc Natl Acad Sci USA 94: 12425-12430, 1997.

27. Polverini PJ: Angiogenesis in health and disease: insights into basic mechanisms and therapeutic opportunities. J Dent Educ 66: 962-975, 2002

28. Gupta K and Zhang J: Angiogenesis: a curse or cure? Postgrad Med J 81: 236-242, 2005.

29. Simpson RJ, Jensen SS and Lim JW: Proteomic profiling of exosomes: current perspectives. Proteomics 8: 4083-4099, 2008.

30. Iero M, Valenti R, Huber V, Filipazzi P, Parmiani G, Fais S and Rivoltini L: Tumour-released exosomes and their implications in cancer immunity. Cell Death Differ 15: 80-88, 2008. 
31. Baj-Krzyworzeka M, Szatanek R, Weglarczyk K, Baran J, Urbanowicz B, Branski P, Ratajczak MZ and Zembala M: Tumour-derived microvesicles carry several surface determinants and mRNA of tumour cells and transfer some of these determinants to monocytes. Cancer Immunol Immunother 55: 808-818, 2006.

32. Valadi H, Ekstrom K, Bossios A, Sjostrand M, Lee JJ and Lotvall JO: Exosome-mediated transfer of mRNAs and microRNAs is a novel mechanism of genetic exchange between cells. Nat Cell Biol 9: 654-659, 2007.

33. de Gassart A, Geminard C, Fevrier B, Raposo G and Vidal M: Lipid raft-associated protein sorting in exosomes. Blood 102: 4336-4344, 2003.

34. Al-Nedawi K, Meehan B, Micallef J, Lhotak V, May L, Guha A and Rak J: Intercellular transfer of the oncogenic receptor EGFRvIII by microvesicles derived from tumour cells. Nat Cell Biol 10: 619-624, 2008.

35. Choi DS, Lee JM, Park GW, Lim HW, Bang JY, Kim YK, Kwon KH, Kwon HJ, Kim KP and Gho YS: Proteomic analysis of microvesicles derived from human colorectal cancer cells. J Proteome Res 6: 4646-4655, 2007.

36. Valenti R, Huber V, Filipazzi P, Pilla L, Sovena G, Villa A, Corbelli A, Fais S, Parmiani G and Rivoltini L: Human tumorreleased microvesicles promote the differentiation of myeloid cells with transforming growth factor-beta-mediated suppressive activity on T lymphocytes. Cancer Res 66: 9290-9298, 2006.

37. Johnstone RM: Exosomes biological significance: A concise review. Blood Cells Mol Dis 36: 315-321, 2006.

38. Giusti I, D'Ascenzo S, Millimaggi D, Taraboletti G, Carta G, Franceschini N, Pavan A and Dolo V: Cathepsin B mediates the $\mathrm{pH}$-dependent proinvasive activity of tumor-shed microvesicles. Neoplasia 10: 481-488, 2008.

39. Huber V, Fais S, Iero M, Lugini L, Canese P, Squarcina P, Zaccheddu A, Colone M, Arancia G, Gentile M, Seregni E, Valenti R, Ballabio G, Belli F, Leo E, Parmiani G and Rivoltini L: Human colorectal cancer cells induce T-cell death through release of proapoptotic microvesicles: role in immune escape. Gastroenterology 128: 1796-1804, 2005.

40. O'Connor R: Concealed cargo within the tumor microenvironment: microvesicles disseminate oncogenic receptors among cancer cells. Cancer Biol Ther 7: 1350-1351, 2008.

41. Deregibus MC, Cantaluppi V, Calogero R, Lo Iacono M, Tetta C, Biancone L, Bruno S, Bussolati B and Camussi G: Endothelial progenitor cell derived microvesicles activate an angiogenic program in endothelial cells by a horizontal transfer of mRNA. Blood 110: 2440-2448, 2007.
42. Ratajczak J, Wysoczynski M, Hayek F, Janowska-Wieczorek A and Ratajczak MZ: Membrane-derived microvesicles: important and underappreciated mediators of cell-to-cell communication. Leukemia 20: 1487-1495, 2006.

43. Ernst M, Najdovska M, Grail D, Lundgren-May T, Buchert M, Tye H, Matthews VB, Armes J, Bhathal PS, Hughes NR, Marcusson EG, Karras JG, Na S, Sedgwick JD, Hertzog PJ and Jenkins BJ: STAT3 and STAT1 mediate IL-11-dependent and inflammation-associated gastric tumorigenesis in gp130 receptor mutant mice. J Clin Invest 118: 1727-1738, 2008.

44. Merchant JL: What lurks beneath: IL-11, via Stat3, promotes inflammation-associated gastric tumorigenesis. J Clin Invest 118: 1628-1631, 2008.

45. Marzesco AM, Janich P, Wilsch-Brauninger M, Dubreuil V, Langenfeld K, Corbeil D and Huttner WB: Release of extracellular membrane particles carrying the stem cell marker prominin-1 (CD133) from neural progenitors and other epithelial cells. J Cell Sci 118: 2849-2858, 2005

46. Florek M, Bauer N, Janich P, Wilsch-Braeuninger M, Fargeas CA, Marzesco AM, Ehninger G, Thiele C, Huttner WB and Corbeil D: Prominin-2 is a cholesterol-binding protein associated with apical and basolateral plasmalemmal protrusions in polarized epithelial cells and released into urine. Cell Tissue Res 328: 31-47, 2007.

47. Lönnroth $C$, Andersson $M$ and Lundholm K: Indomethacin and telomerase activity in tumor growth retardation. Int J Oncol 18: 929-937, 2001.

48. Grau MV, Rees JR and Baron JA: Chemoprevention in gastrointestinal cancers: current status. Basic Clin Pharmacol Toxicol 98: 281-287, 2006.

49. Wang D and Dubois RN: Prostaglandins and cancer. Gut 55: 115-122, 2006.

50. Lönnroth C, Svaninger G, Gelin J, Cahlin C, Iresjö B, Cvetkovska E, Edström S, Andersson M, Svanberg E and Lundholm K: Effects related to indomethacin prolonged survival and decreased tumor growth in a mouse tumor model with cytokine dependent cancer cachexia. Int J Oncol 7: 1405-1413, 1995.

51. Axelsson H, Lönnroth C, Andersson M, Wang W and Lundholm K: Global tumor RNA expression in early establishment of experimental tumor growth and related angiogenesis following COX-inhibition evaluated by microarray analysis. Cancer Inform 3: 125-139, 2007. 